\title{
The Analysis Factor Influence Quality of Life Erderly People in Lemper Pamekasan City
}

Sulistiani
Magister of Public Health Program of
Institut Ilmu Kesehatan STRADA
Indonesia
Email:
publikasistrada@gmail.com

Received : October 12, 2019

Accepted : February 13, 2020

Published : May 12, 2020

\begin{abstract}
Based on the data from WHO in 2015, incident of low birth weight in Indonesia is still high. As many as $15,5 \%$ of babies born in Malang district. in 2018, total babies born were 38.421 and 1261 babies were born with low birth weight (BPS Kab. Malang). Meanwhile in puskesmas dau, there were 30 babies birth with low birth weight. Factors that can influence LBW include maternal weight before pregnancy, maternal weight during pregnancy, arm circumference, alcohol consumption, cigarette use, symptoms of depression or anxiety and eating pattern. This study is a descriptive study with a linear regression analysis design multiple analysis to analyze physical, psychological, and dietary factors in tribulan III pregnant women against LBW events at Puskesmas Dau. Samples were taken by simple random sampling method with a total of 175 pregnant women. The result shows that these three factors had a significant influence on LBW events with a tcount of 2,200 physical condition factors, a t-count of 8,165 psychologic factors, and a t-count of 3,612 eating conditions. Based on the result of this study, it can conclude that there is significant effect between physical factor, psychological factor and eating pattern to low birth weight event in Puskesmas Dau. The conclusion of this study shows that psychological factors that have the most significant influence on LBW events when compared with other factors. Suggestions that can be given from researcher to Puskesmas Dau are to maintain and improve services to psychological conditions by always involving families in solving problems so that low birth weight will decrease
\end{abstract}

Keywords: Physical, Psychological, Eating Pattern And Low Birth Weight 


\section{INTRODUCTION}

Low birth weight babies (LBW) are babies with birth weights of less than 2500 grams regardless of gestational age. LBW can occur in infants ( $<37$ weeks) or in term infants (ec. intrauterine growth restriction) (Pudjiadi, et al., 2010). IMR 24 deaths per 1000 live births in 2017 based on Indonesian demographic and health surveillance (SDKI). Malang Regency in 2017 IMR was 1.61 but in 2018 it became 2.08 per 1000 live births. One of the contributors to infant mortality is LBW, so in pregnancy the mother must be monitored with a quality ANC check. Based on 2015 WHO data, LBW in Indonesia is still high. As many as $15.5 \%$ of babies born in Malang Regency in 2018 babies were born 38,421 of LBW 1261 (BPS Kab.Malang). While in Dau Puskesmas the incidence of LBW in 2018 there were still 30 children.

Berdasarkan data WHO 2015, BBLR di Indonesia masih tinggi. Ditemukan sebanyak $15.5 \%$ dari kelahiran bayi di Kabupaten Malang tahun 2018 dari total bayi lahir 38.421 yang BBLR 1261 (BPS Kab.Malang). Sedangkan di Puskesmas Dau kejadian BBLR tahun 2018 terdapat 30 kelahiran dengan BBLR.

Based on the data from Indonesian demographic and health surveillance (SDKI) in 2017, the infant mortality rate were 1,61 per 1000 babies birth and increase as 2.08 per 1000 babies birth in 2018 . One of many factors that can influence the infant mortality rate was low birth babies weight. So that, all the pregnancy women should be observed by the good quality of antenatal care. Based on the data from WHO in 2015, incident of low babies birth weight in Indonesia is still high. As many as 15,5\% of babies born in Malang district. in 2018, total babies born were 38.421 and 1261 babies were born with low birth weight (BPS Kab. Malang). Meanwhile in Puskesmas Dau, there were 30 babies birth with low birth weight.

Several studies mention factors that can affect low birth weight, including maternal height, maternal weight before pregnancy, maternal weight during pregnancy, arm circumference, alcohol consumption and cigarette use (Kader et al., 2013). Socio-demographic factors that can affect include, the age of pregnant women, primigravida, pregnancy spacing. According to Wado (2014) there are signs of depression symptoms in pregnant women can also affect the baby's weight.

This study aims to analyze the factors that influence the incidence of LBW in third trimester pregnant women including physical, psychological and dietary conditions and determine the factors that most influence the incidence of LBW in pregnant women. This research is a descriptive study with multiple linear regression analysis design. Data were collected using a questionnaire on 175 pregnant women at the Dau Community Health Center. The independent variable of this study was physical, psychological and eating condition factors while the dependent variable of this study was the incidence of LBW in third trimester pregnant women.

\section{METHODS}

This research is a descriptive study with multiple linear regression analysis design. Data were collected using a questionnaire on 175 pregnant women at the Dau Community Health Center. The independent variable of this study was physical, psychological and eating condition factors while the dependent variable of this study was the incidence of LBW in third trimester pregnant women.

\section{RESULTS}

Descriptive Public Data

Table 1 Distribution Frequency Characteristics of Respondents in Dau, District of Malang..

\begin{tabular}{clccc}
\hline No & characteristic & $(\mathrm{f})$ & $(\%)$ \\
\hline 1 & Women & 175 & 100 \\
\hline & Total & 175 & 100.0 \\
\hline 1 & $<20$ years & & \\
\hline 2 & $20-25$ years & & \\
\hline 3 & $25-35$ years & & 100.0 \\
\hline 4 & $>35$ years & 175 & \\
\hline$\quad$ Total & & \\
\hline 1 & Elementary school & & \\
\hline 2 & Junior High School & & \\
\hline
\end{tabular}




\begin{tabular}{clcc}
\hline 3 & Senior High School & & \\
\hline 4 & Diploma/S1 & & \\
\hline & Total & 175 & 100.0 \\
\hline
\end{tabular}

Source : Primary Data (2018)

Based on the results of the study of table 1 of 122 respondents it was mentioned that the characteristics of respondents by gender are mostly $71(58,2 \%)$, almost half of them 65-69 years old 59 $(48,4 \%)$, mostly married $67(54,9 \%), 67(54.9 \%)$ work mostly, and the majority of health status is 79 $(64,8 \%)$.

\section{Custom Data}

Table 2 Distribution Frequency Respondents Based on Special Data in Lemper

Pamekasan Village 2018.

\begin{tabular}{|c|c|c|c|}
\hline No & Physical condition & (f) & $(\%)$ \\
\hline 1 & Normal & & \\
\hline \multirow[t]{2}{*}{2} & Abnormal & & \\
\hline & Total & & \\
\hline No & Psychological & (f) & $(\%)$ \\
\hline 1 & Good & & \\
\hline \multirow[t]{2}{*}{2} & Sufficient/Enough & & \\
\hline & Total & & \\
\hline No & Socialization & (f) & $(\%)$ \\
\hline 1 & Good & & \\
\hline 2 & Sufficient/Enough & & \\
\hline \multirow[t]{2}{*}{3} & Less & & \\
\hline & Total & & \\
\hline No & Eating Pattern & (f) & $(\%)$ \\
\hline 1 & Good & & \\
\hline 2 & Sufficient/Enough & & \\
\hline \multirow[t]{2}{*}{3} & Less & & \\
\hline & Total & & \\
\hline No & Low birth weight event & (f) & $(\%)$ \\
\hline 1 & Good & & \\
\hline 2 & Sufficient/Enough & & \\
\hline \multirow[t]{2}{*}{3} & Less & & \\
\hline & Total & 122 & 100.0 \\
\hline
\end{tabular}

Source : Primary Data (2018)

Based on table 2 the results of this study of 122 respondents found that most of the physical activity both as much as $80(65.6 \%)$, most of the psychological enough as much as $65(53.3 \%)$, almost half sufficient (47.5\%), almost half the socialization is quite as much as $58(47.5 \%)$, the majority of family support is less than 87 (71.3\%), most of the spiritual needs are good as much as $75(61.5 \%)$, and most of the quality of life is quite as much as $89(73,0 \%)$.

Table 3 Cross tabulation The Effects of Physical Activity (X1) oQuality of Elderly Life in Lemper Pamekasan Village in 2018

\begin{tabular}{ccccc}
\hline Variable & \multicolumn{3}{c}{ Quality of Life } & Total \\
\hline Physical Activity & $\mathrm{f} /(\%)$ & $\mathrm{f} /(\%)$ & $\mathrm{f} /(\%)$ & $\mathrm{f} /(\%)$ \\
\hline Good & $1(0,8)$ & $20(16,4)$ & $0(0)$ & $21(17,2)$ \\
\hline Self & $5(4,1)$ & $56(45.9)$ & $19(15,6)$ & $80(65,6)$ \\
\hline
\end{tabular}




\begin{tabular}{ccccc}
\hline Less & $0(0)$ & $13(19,7)$ & $8(6,6)$ & $21(17,2)$ \\
\hline Total & $6(4,9)$ & $89(73,0)$ & $27(22,1)$ & $122(100)$ \\
\hline \multicolumn{5}{c}{ Ordinal regression test, $\alpha=0,029<0,05$} \\
\hline
\end{tabular}

Source : Primary Data (2018)

Based on the table 3 the results showed that of the 122 respondents almost half of respondents physical activity with quality of life is quite as much as $56(45.9 \%)$. Based on ordinal regression statistical test results obtained $\alpha=0.029<0.05$, so Ho rejected means there is influence of physical activity on the quality of life of respondents in the Village Lemper Pamekasan.

Table 4 Cross tabulation Psychological Influence (X2) onQuality of Elderly Life In Lemper Pamekasan Village in 2018

\begin{tabular}{ccccc}
\hline Variable & \multicolumn{3}{c}{ Quality of Life } & Total \\
\hline Psychological & $\mathrm{f} /(\%)$ & $\mathrm{f} /(\%)$ & $\mathrm{f} /(\%)$ & $\mathrm{f} /(\%)$ \\
\hline Good & $2(1,6)$ & $22(18,0)$ & $3(2,5)$ & $27(22,1)$ \\
\hline Enough & $2(1,6)$ & $50(41,0)$ & $13(10,7)$ & $65(53,3)$ \\
\hline Less & $2(1,6)$ & $17(13,9)$ & $11(9,0)$ & $30(24,6)$ \\
\hline Total & $6(4,9)$ & $89(73,0)$ & $27(22,1)$ & $122(100)$ \\
\hline \multicolumn{5}{c}{} \\
\hline
\end{tabular}

Source : Primary Data (2018)

Based on Table 4 the results showed that from 122 respondents almost half of psychological with a quality of life is quite as much as $50(41.0 \%)$. Based on ordinal regression statistical test results obtained $\alpha=0.463>0.05$, so Ho accepted means there is no psychological influence on the quality of life of respondents in the Village Lemper Pamekasan.

Table 5 Cross tabulation Influence of Socialization (X3) on Quality of Elderly Life in Lemper Pamekasan Village in 2018

\begin{tabular}{ccccc}
\hline Variable & \multicolumn{3}{c}{ Quality of Life } & Total \\
\hline Socialization & $\mathrm{f} /(\%)$ & $\mathrm{f} /(\%)$ & $\mathrm{f} /(\%)$ & $\mathrm{f} /(\%)$ \\
\hline \multirow{2}{*}{ Good } & 2 & 16 & 1 & $19(15,6)$ \\
& $(1,6)$ & $(13,1)$ & $(0,8)$ & 58 \\
\multirow{2}{*}{ Enough } & 3 & 42 & 13 & $(47,5)$ \\
& $(2,5)$ & $(34,4)$ & $(10,7)$ & 45 \\
\multirow{2}{*}{ Less } & 1 & 31 & 13 & $(36,9)$ \\
& $(0,8)$ & $(25,4)$ & $(10,7)$ & 122 \\
\multirow{2}{*}{ Total } & 6 & 89 & 27 & $(100)$ \\
& $(4,9)$ & $(73,0)$ & $(22,1)$ & \\
\hline
\end{tabular}

Source : Primary Data (2018)

Based on table 5 the results showed that of the 122 respondents almost half of the socialization with quality of life is quite as much as $42(34.4 \%)$. Based on ordinal regression statistical test results obtained $\alpha=0,529>0,05$, so Ho accepted means there is no influence of socialization on the quality of life of respondents in the Village Lemper Pamekasan.

Table 6 Cross tabulation Influence of Family Support (X4) to Quality of Elderly

Life in Lemper Pamekasan Village in 2018

\begin{tabular}{ccccc}
\hline Variable & \multicolumn{3}{c}{ Quality of Life } & Total \\
\hline Family Support & $\mathrm{f} /(\%)$ & $\mathrm{f} /(\%)$ & $\mathrm{f} /(\%)$ & $\mathrm{f} /(\%)$ \\
\hline Good & $0(0)$ & $10(8,2)$ & $8(6,6)$ & $18(14,8)$ \\
\hline Enough & $3(2,5)$ & $11(9,0)$ & $3(2,5)$ & $17(13,9)$ \\
\hline
\end{tabular}




\begin{tabular}{ccccc}
\hline Less & $3(2,5)$ & $68(55,7)$ & $16(13,1)$ & $87(71,3)$ \\
\hline Total & $6(4,9)$ & $89(73,0)$ & $27(22,1)$ & $122(100)$ \\
\hline & Ordinal regression test, $\alpha=0,024<0,05$ & \\
\hline
\end{tabular}

Source : Primary Data (2018)

Based on table 6 the results showed that of the 122 respondents most of the family support is less with the quality of life is quite as much as $68(55.7 \%)$. Based on ordinal regression statistical test results obtained $\alpha=0.024<0.05$, so Ho rejected means there is influence on the quality of life of respondents in Lemper Pamekasan Village.

Table 7 Cross Tabulation Influence of Spiritual Needs (X5) to Quality of Elderly Life in Lemper Pamekasan Village in 2018

\begin{tabular}{ccccc}
\hline Variable & \multicolumn{3}{c}{ Quality of Life } & Total \\
\hline Spirit Need & $\mathrm{f} /(\%)$ & $\mathrm{f} /(\%)$ & $\mathrm{f} /(\%)$ & $\mathrm{f} /(\%)$ \\
\multirow{2}{*}{ Good } & 1 & 54 & 20 & $75(61,5)$ \\
& $(0,8)$ & $(44,3)$ & $(16,4)$ & 47 \\
\multirow{2}{*}{ Self } & 5 & 35 & 7 & $(38,5)$ \\
& $(4,1)$ & $(28,7)$ & $(5,7)$ & 0 \\
\multirow{2}{*}{ Less } & 0 & 0 & 0 & $(0)$ \\
& $(0)$ & $(0)$ & $(0)$ & 122 \\
\multirow{2}{*}{ Total } & 6 & 89 & 27 & $(100)$ \\
& $(4,9)$ & $(73,0)$ & $(22,1)$ &
\end{tabular}

Source : Primary Data (2018)

Based on Table 4:46 the results showed that of the 122 respondents almost half of his spiritual needs both with quality of life is quite as much as $54(44.3 \%)$. Based on ordinal regression statistical test results obtained $\alpha=0.055>0.05$, so Ho accepted means there is no influence of spriritual needs on the quality of life of respondents in the Village Lemper Pamekasan.

\section{Multivariate analyze (Ordinal Regression)}

Test Statistics to determine the dominant factor family support influence Quality of Life (Y) Respondents (elderly).

\section{DISCUSSION}

\section{Influence of Physical Activity on Quality of Elderly Life}

Based on the result of research indicate that almost half of physical activity of respondent enough with quality of life is enough $56(45,9 \%)$. Based on statistical test result ordinal regresi got $p$ value $(0,029)<0,05$ (Ho rejected) meaning there is influence of physical activity to quality of life of Elderly in Lemper Pamekasan Village. The elderly can use her body functions, so that the body's resistance is good (roads within 20 minutes, jogging, gymnastics, cycling), balance can still be tolerated (like washing clothes, bikes, and sweeps), as well as functional or body strength capabilities that adjust to do heavier work (such as hoeing, grass-seeking and the level of independence of this elderly person in everyday life impact on the quality of his life will also be achieved.

According to Kuntjoro, to maintain good physical and psychological health of elderly it should still do activities useful for his life. This includes the kind of social support that social integration allows the elderly to gain the feeling of belonging to a group that enables them to share interests, concerns, and engage in creative activities together (Fitria, 2011). This is because the elderly can still accept the existing situation in him, can perform activities in accordance with his abilities, still feel happy, and also can enjoy the old age with full meaning, useful and quality. For example, some elderly people are aware and accept with the physical condition that has begun to decline but they still keep the spirit and can do the appropriate activities.

Optimum aging can be interpreted as functional conditions of the elderly are in optimal condition, allowing them to enjoy their parents with full meaning, happy, useful, and quality. Physical 
functioning allows enough elderly to achieve sufficient quality aging. The process and the rate of decline in body functions that occur in these physical changes are very different for each individual even though they are the same age. In addition also on different parts of the body in the same individual processes and varying speed of decline. Expected elderly can make adjustments to the physical changes and health are declining. The declining physical condition makes the elderly feel his life is less meaningful again and despair with the life that is lived today. This becomes one of the marks of the decline as well as the quality of life of the elderly.

This is in line with researcher Supraba (2015) which the results penelitiaannya stated that the quality of life is good for respondents who are physically good activity. Physical activity involves a behavioral component that has two components of movement and behavior. The results of physical activity are numerous and varied when associated with health (physiological and psychological). Physical activity is important to maintain functional ability, strength level and flexibility associated with a person's ability to perform daily life functions such as bathing, dressing. To obtain optimum aging of physical activity of elderly is very necessary, for example exercise done regularly and regularly will very help fitness and keep psychomotor ability of elderly. Physical activity may delay the decline in strength if associated with the aging process. The need is needed by the elderly to be independent. The need is in line with Maslow's opinion in Koswara (2011) which states that human needs include physical needs (physiological needs) are physical or biological needs such as food, clothing, boards, sex and so on.

To obtain optimum aging of elderly physical activity is very necessary, for example sports (senan elderly, tera gymnastics and physical exercise (Elderly or in accordance with the disease), range of motion (exercise flexibility) or joints and relaxation done regularly and regularly will be very helpful fitness and maintenance of psychomotor ability of elderly, so as to improve physical endurance, muscle strength and body flexibility Psychomotoric function (konatif) include matters relating to the will of the will such as movement, action, coordination, which resulted in the Elderly become less nimble. will have an effect on all aspects of life including their health.Therefore, Elderly health needs special attention by maintaining and improving to the extent possible to live productively according to their abilities.On the Elderly with work requiring manpower no longer fit, huh s switch to more work using the brain than the muscle, the ability to perform daily activities (Activity Daily Living / ADL) has also decreased. Based on the results of the study showed that of the 122 respondents almost half were married with sufficient physical activity as much as 48 (39.3\%). Based on the results of chi-square test obtained $\mathrm{p}$ value $=0.038<0.05$ means there is a relationship of marital status with physical activity of respondents. Respondents aged between 65-69 years have been married and experience life with a variety of joys and sorrows both of themselves (individual), family and social environment, so it is wiser in the face of the problems of changes that experienced in his old age. According to Coons and Kaplan quoted by Chairani (2013) said that everyone has a different quality of life depending on each individual in addressing the problems that occur within him. If faced with a positive it will be good quality of life, but it is different if faced with the negative it will be bad also the quality of life. According to Wagner said that age affects the quality of one's life so that the elderly can still move. This is in accordance with the results of research showing that age affects each domain (Chairani, 2013). Respondents can still function the ability of joint function and muscle strength even though still in stiffness and pain experienced, with routine work and motion performed in the morning can be passed with a good enough movement to move in and out of the house such as helping in cleaning the house, , raising and farming as well as to meet their basic needs. According to Azizah (2011) a person experiencing a physical, mental and social slowdown gradually in this period. Changes in the body occur with age but the effects on humans are very dependent on health, habits of life, stressors, and environmental conditions. Elderly (Elderly) who is still less physical activity due to age factor that began to grow weak and muscles decline and weaken. Based on the result of research indicate that most of the sick respondents were $79(64,8 \%)$ and almost half were healthy as many as $43(35,2 \%)$. Based on existing theory, in general elderly women experience complaints of acute and chronic pain is higher than men so that it can affect the quality of life. This is in line with previous research which states that sex is related to the quality of life of elderly Simanullang, (2011) with the title of lifestyle influence on health status. Physical state or health disorder is a manifestation of the decrease of cell regeneration / production of replacement cells and functional, so it can affect the Elderly physical activity. Physical state is a major factor of human anxiety. Physical strength, senses, potential and intellectual capacity 
begin to decline at certain stages (Prasetyo, 2013). The aged must adapt again with his helplessness. Physical degeneration is characterized by several diseases such as disorders of the blood circulation, joints, respiratory system, neurologic, metabolic, neoplasm and mental, so the frequent complaints are easily tired, forgetful, digestive disorders, urinary tract, sensory function and decreased concentration . To examine the physic of the elderly, consideration should be given to their existence such as decreased hearing, vision, limited movement, and slow response time. The activities of everyday life such as movement, action, coordination which result that the elderly are less nimble. The quality of life of the elderly can be judged by the ability to perform daily activities of life, such as the ability to care for oneself such as eating, dressing, defecating and bathing, and complex activities such as cooking, washing, using the phone, and using money. Some studies have shown a decrease in the quality of life of elderly people due to the disease process (physiological) in elderly, such as decreased quality of life in elderly with stroke, decreased quality of life of elderly with diabetes mellitus disease. But not yet found a lot of research about how the quality of life elderly when viewed from the social and environmental aspects, but it is also very influential on the quality of life of the elderly. Some elderly people end up having psychological as well as physical problems, such as pathological on physical condition such as chronic diseases and psychic conditions such as stress, depression, loneliness and even commit suicide (Salamah, 2015). It causes a change in the quality of life.

\section{Psychological Influence to quality of life Elderly}

Based on the results of the research show that almost half of respondents to the psychological quality of her quite as much as $50(41.0 \%)$. Based on the results of the statistical tests ordinal regression obtained the value of $p(0.463)>0.05$ (Ho accepted) means that there is no psychological influence to quality of life Elderly in the village of Pamekasan Lemper.Old age is experienced with different ways. There are older people who are able to see the significance of old age in the context of human existence, that of life that give them opportunities to grow.There are also elderly who looked at old age with attitudes ranging from passive acceptance and rebellion, rejection, and despair.This elderly into locked inside themselves and thus the sooner the process of physical and mental deterioration of their own.This contrasts with research results from Rohmah (2012) there is a psychological quality of life against oengaruh lannsia.that is in line with the results of the study Princess dkk (2014) that in the domain of psychological, Elderly living in majority $(73.8 \%)$ have a sufficient quality of life.The answer really depends on the individual's mental attitude in the face of old age.In fact there are received, there is a fear of losing, there was pleased to have the assurance of the old days and there's also that seems indifferent towards her condition (resigned).Each of these attitudes actually have impact for each individual, both positive and negative.Positive impact more reassuring themselves elderly and negative impact would disrupt the welfare of elderly life.Psychological well-being include influence, fulfillment, stress and mental state, self-esteem, respect, status and religious beliefs, and sexuality.During the next age, a person will experience changes in terms of physical, cognitive, as well as in the life of psikososialnya (Papalia, Olds, \& Feldman, 2001; Ariyanti, 2009). The stability of psychological wellbeing becomes one of the factors which play a role in improving the psychological well-being (Renwick $\&$ Brown, 1996).

Psychological health refers to positive affects, spirituality, thinking, learning, memory and concentration, self-image and appearance, self-worth, and negative affects. Psychological change comes from awareness of degeneration and inferiority when compared to younger people, strength, speed, and skill. At the stage of development of the elderly, the main developmental task is to understand and accept the changes physical and psychological changes experienced, and use his life experience to adjust to physical and psychological changes. Duties in development are patterns of behavior that are agreed at all ages throughout the vulnerable life. The definition is the task that arises during or about a certain period of the life of the individual, which if successful will lead to a sense of happiness and lead to success in carrying out the next tasks. However, if it fails will cause difficulties in facing the next task. 


\section{CONCLUSION}

There is influence of physical activity to quality of life of Elderly in Lemper Pamekasan Village with $p$ value $=0,029$.

There is no psychological influence on the quality of life of the Elderly in Lemper Pamekasan Village with $\mathrm{p}=0,463$.

There is no socio-economic influence on the life quality of the Elderly in Lemper Pamekasan Village with $\mathrm{p}=0,529$.

There is influence of family support to quality of life of Elderly in Lemper Pamekasan Village with $p$ value $=0,024$.

There is no influence of spiritual needs on the quality of life of the Elderly in Lemper Pamekasan Village with $\mathrm{p}=0,055$.

The dominant factor of family support on the quality of life of the elderly in Lemper Pamekasan village with $\mathrm{p}$ value $=0,024$

\section{REFERENCES}

Alza, N., \& Ismarwati. (2017). Faktor-Faktor Yang Mempengaruhi Kecemasan Ibu Hamil Trimester III. Kebidanan Dan Keperawatan, 13(1), 2.

Saputra, A., \& Bersalin, R. (2011). ANTROPOMETRI BAYI BARU LAHIR DI ACEH BESAR Effect of Physiological Changes in Pregnant Women Toward New Born Baby' s Anthropometry i

Anandya, P. (2018). PENELITIAN Analisis Faktor-faktor yang Berhubungan dengan Kejadian BBLR di Rumah Sakit, 7(2), 113-119.

Astuti, A. B., santosa, S. W. \& utami, M. S. (2015). Hubungan Antara Dukungan Keluarga dengan Penyesuaian Diri Perempuan pada Kehamilan Pertama. Journal e-Biomedik.

Badan Pusat Statistik. 2017. Statistik Daerah Kecamatan Dau 2017.BPS: Kab. Malang

Biaggi, A., conroy, S., pawbiy, S. \& pariante, C. 2016. Identifying the women risk of antenatal anxiety and depression: a systematic review. Journal of Affective Disorders, 191, 62-77.

Djaja, S., \& Soemantri, S. (2003). Penyebeb Kematian Bayi Baru Lahir (Neonatal) dan Sistem Pelayanan Kesehatan yang berkaitan di Indonesia Puslitbang Ekologi Kesehatan, 31(3), 155165.

Dole, N., savitz, D. A., Picciotto, H., riz, A. M. S., Mcmahon, M. J. \& buekens. (2003). Maternal Stress and Preterm Birth. Oxford Academic, 157.

Firizqina, A. B., Romadhon, Y. A. \& Candasari, A. (2016). Hubungan antara kenaikan berat badan ibu hamil Dengan kejadian bayi berat lahir rendah (bblr) Di Kabupaten Semarang. Muhammadiyah University.

Fretes, E.D., Warsono, H. , \& Sriatmi, A. (2016). Analisis Pelaksanaan Program Kemitraan Bidan dan Dukun Ditinjau Dari Aspek Input, Proses dan Output di Wilayah Dinas Kesehatan Kabupaten

Fakfak Provinsi Papua Barat. Jurnal Manajemen Kesehatan Indonesia, 4(3).

Fuada, N. , \& Setyawati, B. (2013). Pelaksanaan Kelas Ibu Hamil di Indonesia. Litbangkes Kemenkes. Hasmeinda Marindratama. (2014). Trimester Iii Dengan Berat Bayi Lahir Di Kabupaten Semarang.

Hartiningrum, I., \& Fitriyah, N. (2018). Bayi Berat Lahir Rendah (BBLR) di Provinsi Jaa Timur Tahung 2012-2016.

Kemenkes RI. 2013. Riset Kesehatan Dasar; RISKESDAS. Jakarta: Balitbang Kemenkes RI

King, J. C. (2000). Physiology of pregnancy and nutrient metabolism. American Society for Clinical Nutrition, 7(12185-1225S).

Lza, N. \& Ismarawati 2017. Faktor-Faktor yang Mempengaruhi Kecemasan Ibu Hamil Tribulan III. Jurnal Kebidanan dan Keperawatan, 13, 1-6.

Marhaeni, D. , \& Herawati, D. (2016). Decision Space dalam Program Kesehatan Ibu dan Anak Tahun 2016. Jurnal Manajemen Pelayanan Lesehatan, 9(3), 118-120.

Marindratama, H. (2014). Hubungan Pertambahan Berat Badan Ibu Hamil Trimester Iii Dengan Berat Bayi Lahir Di Kabupaten Semarang

Marlenywati, Hariyadi, D. , \& Ichtiyati, F. (2015). Faktor-Faktor yang Mempengaruhi Kejadian BBLR d RSUD Dr. Soedarso Pontianak. Jurnal Vokasi Kesehatan, 1(5), 154 - 160. 
Narasiang, B. R. \& Kawengian, S. (2016). Gambaran Pola Konsumsi Makanan pada Ibu Hamil di Kota Manado.

Pudjiadi Antonius, H., Hegar Badriul, dkk. (2010). Pedoman Pelayanan Medis Ikatan Dokter Anak Indonesia.Jakarta: IDAI

Purwanto. (2017). Relationship Between the Age Pregnancy, Multiple Pregnancy, Hypertension and Anemia with Incidenceof Low Birth Weight (LBW).

Ratnasari, D., Suhartono, \& Rahfiludin, M.Z. (2017). Faktor Risiko Kejadian Berat Badan Lahir Rendah di Area Pertanian (Studi Kabupaten Brebes). J. Gizi Pangan, 12(1), 41-48.

Rustikayanti, R.N., Kartika, I. , \& Herawati, Y. (2016). Perubahan Psikologis pada Ibu Hamil Trimester III. SThe Southeast Asian Journal of Midwifery, 2(1), 45-49.

SDKI. (2012). Survei demografi dan kesehatan Indonesia. Jakarta

Setyawati, B., \& Syauqy, A. (2014). Perbedaan Asupan Protein, Zat Besi, Asam Folat, Dan Vitamin B12 Antara Ibu Hamil Trimester Iii Anemia Dan Tidak Anemia Di Puskesmas Tanggungharjo Kabupaten Grobogan. Journal of Nutrition College, 3(1), 229.

Simanjuntak, D.H., \& Sudaryati, E. (2015). Gizi pada Ibu Hamil dan Menyusui. Digital Libary USU, 78-82.

Soma-Pillay, P., Nelson-Piercy, C. , Tolppanen, H., \& Mebazaa, A. (2016). Physiological changes in pregnancy. Cardiovasular Journal of Africa, 27(2), 89-94.

Soma-pillay, P., Nelson-piercy, C., Tolppanen, H., \& Mebazaa, A. (2016). Physiological changes in pregnancy, 27(2), 89-94. https://doi.org/10.5830/CVJA-2016-021

UNICEF. Ringkasan Kajian Gizi. Jakarta: Pusat Promosi Kesehatan -Kementerian Kesehatan RI; 2004

Wado, Y. D., Afework, M. F. \& Hindin, M. J. (2014). Effects of Maternal Pregnancy Intention, Depressive Symptoms and Social Support on Risk of Low Birth Weight: A Prospective Study from Southwestern Ethiopia. Plos One, 9.

World Health Organization. 2004. International Statistical Classification of Disease and Related Health Problems Tenth Revision Volume 2second edition. Geneva: World Health Organization

WHO. Millennium Development Goals (MDGs). Jakarta: United Nation; 2008

WHO. World Health Statistics 2015: World Health Organization; 2015 